\title{
31. 先天代謝異常症における骨餚移植のメカニスムに関する研究
}

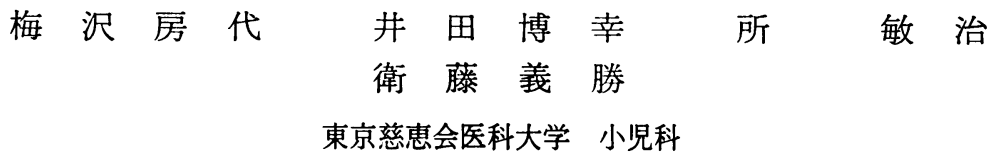

先天代謝異常症の治療としては, 従来までに酵素補 充㞠法・臓器移植などが試みられているが，投与方法 や経済的な面で問題が残されている. 最近, これらの 疾患に骨髄移植が行われその効果が認められるように なってきた.とくに ALD や Krabbe 病などの中权 神経に障害を有する疾患においても, 早期に骨髄移植 を行えば治療効果があるとの報告もみられている11.

しかし骨㵦移植の効果のメカニズムに関しては不明な 点が多い。

そこでわれわれは，ヒト Krabbe 病のモデル動物で ある Twitcher mouse を用いこのメカニズムに関し て検討した.

\section{対象と方法}

使用したマウスは米国ジャクソン社より入手した B6/CE strain で, heterozygote 同士の交配により homozygote を得た. マウスの診断は，小林ら²)の方 法により生後 2 週目までの尾の cerebroside $\beta$-galactosidase 活性を測定して行った.

（1）骨髄細胞は，正常同系マウスの下肢より採取し

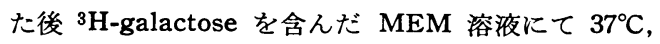
24 時間 incubation ᄂ, 洗浄後 $10^{6}$ 個 $/ 0.2 \mathrm{ml}$ の浮遊 液としマウス腹腔内に投与した．投与前，マウスには $800 \mathrm{rad}$ の全身照射を行い，また骨䯣細胞投与日より 5 日間サイクロスポリン $15 \mathrm{mg} / \mathrm{kg} / \mathrm{day}$ を投与する 群としない群の二つに分けた。投与後継時的にマウス 臓器におけるアイントープの取り込みの分布を検討し た.

さらに, 脳内への骨䯣細胞の取り込みの有無を形態 的にとらえるため, 骨髄細胞を PHA で 10 分間 incubation した後洗浄し PHA を膜にラベルしてマウ ス腹腔内に投与した。投与後 $3,5,7,14$ 日で殺し $20 \mu \mathrm{m}$ の脳の超薄切片を作成し, PHA の抗体と ABC キットを用い免疫組織学的に脳内の発色の有無を検討 した.

（2）酵素を含有しない ${ }^{3} \mathrm{H}$-gal-cer ラベルの liposome 3 日間 pulse した後, 骨䯣細胞投与群と非投
与群で外来性に蓄積させた ${ }^{3} \mathrm{H}-$ gal-cer のクリアラン スに差がみられるかどらかを検討した。

秸 果

(1) 3H-galactose でラベルした骨髄細胞の取り込み は，脳ではサイクロスポリン投与群と非投与群で差は 認められなかった. しかし, homozygote では全投与 量の $10 \%$ が脳汇取り込まれ，正常マウスの 2 3\% に比し高値を示した. 肝においては, homozygote 群 にやはり取り込みが高かったが，中でもサイクロスポ リン投与群により優位に取り込みが高くみられた.

PHA を用いた免疫組織学的検討では, PHA 陽性を 示す細胞群が脳実質および血管周囲に散在する像を, 投与後 2 週の脳組織において認めた.

(2) 酵素を含有しない liposome の投与では, 脳で は正常および homozygote マウスで有意差なく, 肝 では homozygote マウスに 5 6 倍量の ${ }^{3} \mathrm{H}$-gal-cer の蓄積が認められた，骨髄細胞投与群では, homozygote 脳では投与前の $75 \%$ まで, 肝では $10 \%$ まで アイントープ量が低下した. しかし骨䯣細胞非投与群 との有意差は認められなかった。

考察

骨髄移植の効果のメカニズムとしては，1）metabolic filtration, 2) enzyme replacement, 3) cell transplantation の可能性が示唆されている. 今回の 結果より, アイントープ量として脳組織でとらえられ かつレクチンラベルした練胞を形態的に証明しえたこ とより3）のメカニズムが最も強く考劣られた．しか し外来性に蓄積させた ${ }^{3} \mathrm{H}-$ gal-cer のクリアランスは 骨䯣細胞投与の有無に関わらず差がなかったことより (2)のメカニズムは証明しえなかった. 今後，より長期 にわたる検討が必要と思われた。

文 献

1) Demetriou, A.A. et al. : Science, 233, 1190 (1986)

2) Kobayashi, T. et al. : Biochem. Med., 27, 8 (1982) 